\title{
Interaction with activated monocytes enhances cytokine expression and suppressive activity of human CD4+CD45RO+CD25+CD127low regulatory T cells
}

\author{
Gina J. Walter ${ }^{1}$, Hayley G. Evans, PhD ${ }^{1}$, Bina Menon, MD ${ }^{1,2,3}$, Nicola J. Gullick ${ }^{4}$, Bruce W. \\ Kirkham, $\mathbf{M D}^{2}$, Andrew P. Cope, MD, $\mathrm{PhD}^{1,2,3}$, Frédéric Geissmann, MD, $\mathrm{PhD}^{1}$, and Leonie \\ S. Taams, $\mathrm{PhD}^{1, *}$ \\ ${ }^{1}$ Centre for Molecular and Cellular Biology of Inflammation (CMCBI), Division of Immunology, \\ Infection and Inflammatory Disease, King's College London, London, UK \\ 'Department Rheumatology, Guy's \& St Thomas' NHS Foundation Trust, London, UK \\ ${ }^{3}$ Academic Department Rheumatology, King's College London, London, UK \\ ${ }^{4}$ Department Rheumatology, King's College Hospital NHS Foundation Trust, London, UK
}

\begin{abstract}
Objective-Despite the high frequency of $\mathrm{CD} 4^{+} \mathrm{T}$ cells with a regulatory phenotype $\left(\mathrm{CD} 25^{+} \mathrm{CD} 127^{\text {low }} \mathrm{FoxP}^{+}\right)$in the joints of patients with rheumatoid arthritis (RA), inflammation persists. One possible explanation is that human Tregs are converted into pro-inflammatory IL-17producing cells by inflammatory mediators and thereby lose their suppressive function. We investigated whether activated monocytes, which are potent producers of inflammatory cytokines and abundantly present in the rheumatic joint, induce pro-inflammatory cytokine expression in human Tregs and impair their regulatory function.
\end{abstract}

Methods-The presence and phenotype of $\mathrm{CD} 4{ }^{+} \mathrm{CD} 45 \mathrm{RO}^{+} \mathrm{CD} 25^{+} \mathrm{CD} 127^{\text {low }} \mathrm{T}$ cells (memory Tregs) and $\mathrm{CD} 14^{+}$monocytes in the peripheral blood (PB) and synovial fluid (SF) from patients with RA was investigated by flow cytometry. FACS-sorted memory Tregs from healthy controls were co-cultured with autologous activated monocytes and stimulated with anti-CD3 monoclonal antibody. Intracellular cytokine expression, phenotype and function of cells were determined by flow cytometry, ELISA and proliferation assays.

Results-Patients with RA showed higher frequencies of $\mathrm{CD} 4{ }^{+} \mathrm{CD} 45 \mathrm{RO}^{+} \mathrm{CD} 25^{+} \mathrm{CD} 127^{\text {low }}$ Tregs and activated $\mathrm{CD} 14^{+}$monocytes in SF relative to $\mathrm{PB}$. In vitro-activated monocytes induced an increase in the percentage of IL- $17^{+}$, IFN $\gamma^{+}$and TNF- $\mathrm{a}^{+}$, but also IL- $10^{+}$Tregs. The observed increase in IL- $17^{+}$and IFN $\gamma^{+}$Tregs was driven by monocyte-derived IL-1 $\beta$, IL- 6 and TNF- $\alpha$ and was mediated by both $\mathrm{CD} 14^{+} \mathrm{CD} 16^{-}$and $\mathrm{CD} 14^{+} \mathrm{CD} 16^{+}$monocyte subsets. Despite enhanced cytokine expression, cells maintained their $\mathrm{CD} 25^{+} \mathrm{FoxP} 3{ }^{+} \mathrm{CD} 39^{+}$Treg phenotype and showed enhanced capacity to suppress proliferation and IL-17 production by effector T cells.

Conclusion-Tregs exposed to a pro-inflammatory environment show increased cytokine expression as well as enhanced suppressive activity.

*Correspondence and reprint requests should be addressed to: Leonie S. Taams, PhD, Centre for Molecular and Cellular Biology of Inflammation (CMCBI), $1^{\text {st }}$ Floor New Hunt's House, Room 1.26F, Guy's Campus, King's College London, London SE1 1UL, United Kingdom, Telephone: +44-207-848-8633, leonie.taams@kcl.ac.uk.

BWK has received consultancies, speaking fees or honoraria $(<\$ 10,000)$ from Abbott, Pfizer, UCB, Roche, BMS. The other authors report no conflicts of interests related to this work. 
Immune regulation is essential for the maintenance of peripheral tolerance, prevention of autoimmune diseases and the limitation of chronic inflammation. Human $\mathrm{CD} 4{ }^{+} \mathrm{CD} 25^{+} \mathrm{CD} 127^{\text {low }}$ regulatory T cells (Tregs), characterised by the expression of the lineage-specific transcription factor FoxP3, are important immune regulators through their ability to suppress activation, proliferation and effector functions of a wide range of immune cells including $\mathrm{CD}^{+}$and $\mathrm{CD} 8^{+} \mathrm{T}$ cells, B cells, NK cells and APCs (reviewed in $(1,2)$ ). The notion that $\mathrm{CD} 4^{+} \mathrm{CD} 25^{+} \mathrm{CD} 127^{\text {low }} \mathrm{Foxp} 3^{+} \mathrm{T}$ cells are terminally differentiated suppressor cells has been challenged by reports showing that Tregs can display significant plasticity during development and differentiation in the periphery in response to extrinsic cues (reviewed in $(3,4)$ ). The concept of Treg plasticity has raised fundamental questions regarding the significance of $\mathrm{CD} 4{ }^{+} \mathrm{CD} 25^{+} \mathrm{CD} 127^{\text {low }}{ }^{\mathrm{Foxp}} 3^{+}$Tregs present at sites of inflammation as well as the stability and safety of ex vivo-expanded human Tregs for the use in immunotherapy.

A landmark study by Miyara et al. revealed that Tregs from human peripheral blood are heterogeneous, comprising at least three phenotypically and functionally distinct populations. The so called population III (CD45RA-FoxP3 ${ }^{\text {low }}$ ) was shown to be nonsuppressive and able to convert into IL-17-producing cells (5). The in vivo existence of IL- $17^{+}$Tregs has been demonstrated in human peripheral blood $(6,7)$ as well as in periodontitis lesions (8) and skin lesions of patients with severe psoriasis (9). Several groups have identified the pro-inflammatory cytokine IL-1 $\beta$ as a critical mediator in the conversion of human Tregs into IL-17-producing cells in vitro $(6,7,10-13)$. As yet, data are conflicting as to whether these pro-inflammatory cytokine-producing Tregs are impaired in their regulatory function. Furthermore, since most of these studies have been performed using aCD3/CD28 beads and recombinant cytokines, data on human Treg conversion in a physiological context are scarce.

IL-17 has been associated with inflammatory diseases such as rheumatoid arthritis (RA), inflammatory bowel disease, multiple sclerosis, asthma, systemic lupus erythematosus, psoriasis and type 1 diabetes (reviewed in (14)). Previous work from our lab has shown that $\mathrm{CD}_{1}{ }^{+}$cells are present in large numbers in the synovial fluid of patients with RA and that these cells preferentially promote Th17 responses in $\mathrm{CD} 4^{+} \mathrm{T}$ cells $(15) . \mathrm{CD}^{+} 4^{+}$monocytes are important contributors to inflammation through the production of pro-inflammatory cytokines such as IL-1 $\beta$. Based on these findings we sought to determine whether activated monocytes drive the expression of IL-17 in highly purified $\mathrm{CD} 4^{+} \mathrm{CD} 45 \mathrm{RO}^{+} \mathrm{CD} 25^{+} \mathrm{CD} 127^{\text {low }}$ regulatory $\mathrm{T}$ cells (memory Tregs), and whether this affects Treg phenotype and function. We report here that human memory Tregs, in the presence of activated monocytes, display increased expression of both pro- and antiinflammatory cytokines. These cells maintain their Treg phenotype and exert enhanced suppressive effects on $\mathrm{T}$ cell proliferation and cytokine production.

\section{Materials \& Methods}

\section{Patients and healthy volunteers}

Peripheral blood (PB, $n=29)$ and synovial fluid (SF, n=12) was obtained from patients with rheumatoid arthritis (RA) recruited from Guy's and St Thomas' Hospital NHS Trust. PB was also collected from adult healthy controls (HC). The mean age of patients and $\mathrm{HC}$ was $58 \pm 2.8$ and $36 \pm 2.2$ years, respectively. Female to male ratios were 26:3 (patients) and 24:12 (HC). The mean patients' DAS28 score was 5.2 \pm 0.3 (mean \pm SEM, $n=18$ ); $5 / 29$ patients were on TNF inhibitor therapy, 18/29 on DMARD, and 3/29 on steroids or NSAIDs. All participants gave written informed consent. Ethics approval for this study was given by the Bromley Research Ethics Committee (06/Q0705/20). Mononuclear cells were isolated from 
PB and SF using Ficoll-Hypaque (LSM 1077, PAA, Pasching, Austria) density gradient centrifugation.

\section{Phenotypic analysis}

The following monoclonal antibodies ( $\mathrm{mAb}$ ) were used: CD2-PacificBlue (clone: TS18), CD3-APC/Cy7 (clone: HIT3a), CD4-PerCP/Cy5.5 (clone: SK3), CD14-APC/Cy7 (clone: HCD14), CD16-AlexaFluor488 (clone: 3G8), CD39-PE/Cy7 (clone: A1), CD45ROPacificBlue (clone: UCHL1), CD54-AlexaFluor647 (clone: HCD54), CD86-PacificBlue (clone: IT2.2), CD127-AlexaFluor488 (clone: HCD127) and CD161-AlexaFluor647 (clone: HP-3G10) all from BioLegend (San Diego CA, USA), CD25-PE (clone: 4E3) from Miltenyi Biotec (Bergisch Gladbach, Germany), CD40-PE (clone: LOB7/6) and CD69-PE (clone: FN50) from AbD Serotec (Kidlington, UK) and HLA-DR-PerCP/Cy5.5 (clone: G46-6) from BD (Franklin Lakes NJ, USA). For intracellular cytokine staining (ICCS), cells were stained for $\mathrm{CD} 2$ and $\mathrm{CD} 14$, followed by fixation with $2 \%$ PFA. Cells were then stained intracellularly with IL-10-AlexaFluor488 (clone: JES3-9D7), IL-17A-PE (clone: BL168), TNF-a-APC (clone: MAb11) and IFN $\gamma$-PerCP/Cy5.5 (clone: 4S.B3) (all from BioLegend) using $0.5 \%$ Saponin. For intranuclear staining, cells were extracellularly stained and fixed as described above followed by permeabilization with $1 \times$ FoxP3 perm buffer (BioLegend). Cells were then stained with FoxP3-AlexaFluor647 (clone: 259D) and Ki-67-AlexaFluor488 (clone: Ki-67) from BioLegend in combination with IL-17-PE. Cells were acquired on a BD FACSCantoII and analysed using FlowJo 7.6.1 software (Tree Star Inc., Ashland OR, USA).

\section{Cell isolation}

Peripheral blood mononuclear cells (PBMC) were incubated with CD14 MicroBeads (Miltenyi Biotec) for positive selection of $\mathrm{CD} 14^{+}$monocytes by magnetic cell separation. Purity was confirmed by flow cytometry and was consistently $>97 \%$. The CD14 fraction was used for memory $\mathrm{CD} 4^{+} \mathrm{T}$ cell isolation by negative selection (Miltenyi Biotec) according to the manufacturer's instructions and purity of cells was always $>96 \%$. Memory $\mathrm{CD}^{+} \mathrm{T}$ cells were stained with CD25-PE and CD127-FITC (clone: A019D5, BioLegend) and sorted into $\mathrm{CD} 25^{+} \mathrm{CD} 127^{\text {low }}$ Tregs and CD25 ${ }^{\text {low/-}} \mathrm{CD} 127^{+}$effector T cells (Teff) using a BD FACS Aria ${ }^{\mathrm{TM}}$ II cell sorter (purities $>97 \%$, Supplementary Figure 1). Where indicated, isolated $\mathrm{CD} 14^{+}$monocytes were stained with CD16-AlexaFluor488 after incubation with FcR blocking reagent (Miltenyi Biotec) and sorted into $\mathrm{CD} 16^{+}$and $\mathrm{CD} 16^{-}$cells (Supplementary Figure 2).

\section{Co-culture experiments}

Cells were cultured in culture medium (RPMI 1640 (Gibco®, Camarillo CA, USA), 20mM L-glutamine (Gibco®), 1\% Penicillin-Streptomycin (Gibco ${ }^{\circledR}$ ) and 10\% FCS (Sigma, St. Louis MO, USA) at $37^{\circ} \mathrm{C}$ and $5 \% \mathrm{CO}_{2}$. Monocytes $\left(10 \times 10^{6} / \mathrm{ml}\right)$ were pre-incubated with medium, 100ng/ml LPS (Sigma), or a cytokine cocktail consisting of hrIL-1 $\beta$, IL-6, IL-10, IL-17, TNF-a, OPN (all at 10ng/ml) and 10U/ml IFN $\gamma$ (all from R\&D, Minneapolis MN, USA) for $30 \mathrm{~min}$. Following incubation, cells were washed twice with 5-10ml of medium and recounted.

Monocytes $\left(1 \times 10^{5}\right)$ were co-cultured at a 1:1 ratio with sorted $\mathrm{CD}^{+} \mathrm{CD} 45 \mathrm{RO}^{+} \mathrm{CD} 25^{+} \mathrm{CD} 127^{\text {low }}$ Tregs or $\mathrm{CD} 4^{+} \mathrm{CD} 45 \mathrm{RO}^{+} \mathrm{CD} 25^{\text {low }}-\mathrm{CD} 127^{+}$Teff and $100 \mathrm{ng} / \mathrm{ml}$ soluble anti-CD3 mAb (Okt-3, Janssen-Cilag, Buckinghamshire, UK) in a total volume of 250 $\mathrm{\mu l}$. At day 3, cells were stimulated with 50ng/ml PMA (Sigma) and 750ng/ml ionomycin (Sigma) for 6hrs, with GolgiStop ${ }^{\mathrm{TM}}$ (BD) present for the last $3 \mathrm{hrs}$. Where supernatants of activated monocytes were transferred, these were collected from autologous or allogeneic LPS-pre-activated monocytes after $40 \mathrm{hrs}$ and added 1:1 (v/v) to co-cultures. For blocking experiments, neutralising antibodies against IL-1 $(1 \mu \mathrm{g} / \mathrm{ml}$, clone: 8516 , 


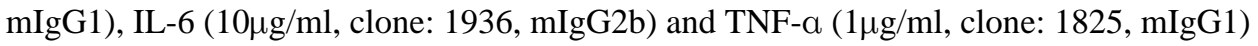
(all from R\&D) were added at the start of culture.

\section{Suppression assay}

Freshly sorted Teff $\left(2-5 \times 10^{6} / \mathrm{ml}\right)$ were labelled with $2 \mu \mathrm{M}$ carboxyfluorescein succinimidyl ester (CFSE, Molecular Probes ${ }^{\mathrm{TM}}$, Eugene OR, USA) according to manufacturer's instructions. Cells were washed, recounted and plated in a 24 -well plate $\left(1 \times 10^{6} / \mathrm{ml}\right)$. At the same time, unlabelled, sorted Tregs at various concentrations $\left(1 \times 10^{4}-5 \times 10^{4}\right)$ were cultured with anti-CD3 mAb and $5 \times 10^{4}$ monocytes pre-treated with either LPS or medium in a total volume of $100 \mu 1$. The next day, CFSE-labelled Teff were taken off the plate, washed, recounted and $5 \times 10^{4}$ cells added to the Treg-monocyte co-cultures. To determine proliferation, fluorescence was assessed 2 days later by flow cytometry and percentage of suppression was calculated using the formula: $\{100-[(\%$ dividing cells (condition w/ Treg) /\% dividing cells (condition w/o Treg)] $* 100)\}$.

\section{Cytokine analysis}

Supernatants of co-cultures were collected on day 3, after re-stimulation with PMA and ionomycin, centrifuged to remove cell debris and stored at $-80^{\circ} \mathrm{C}$ until analysed. IL-1 $\beta$ (R\&D Systems), IL-6, IL-17, IFN $\gamma$ and TNF-a (BioLegend) levels were determined using enzyme-linked immunosorbent assay (ELISA) according to manufacturers' protocols. Supernatants from monocytes stimulated with either medium or LPS for 40hrs, were analysed using the Human Cytokine 25-plex kit (Invitrogen Life Technologies, Camarillo CA, USA) on the Luminex ${ }^{\circledR}$ platform (Austin TX, USA). For detection of cytokines in SF of patients with RA, FlowCytomix ${ }^{\mathrm{TM}}$ Th1/Th2 assay (eBioscience, Hatfield, UK), IL-17 and OPN ELISA (R\&D Systems) were used.

\section{Statistical analysis}

Significance testing was performed using Prism 5 software (GraphPad, San Diego CA, USA). Data were tested for normality using D'Agostino and Pearson omnibus normality test, followed by the appropriate parametric or non-parametric test, as indicated in the figure legends.

\section{Results \\ $C D 4{ }^{+} C D 45 R O^{+} T$ cells with a regulatory phenotype and activated CD14+ monocytes are abundantly present at the site of inflammation in patients with RA}

Various reports, including our previous work, have demonstrated increased frequencies of $\mathrm{CD} 4{ }^{+} \mathrm{CD} 25^{+}$Tregs in the synovial fluid (SF) of patients with rheumatoid arthritis (RA) compared to peripheral blood (PB) (16-23). However, these studies did not account for the fact that virtually all $\mathrm{T}$ cells in SF have a memory $\mathrm{CD}^{-} 5 \mathrm{RO}^{+}$phenotype, whilst their blood counterparts comprise both $\mathrm{CD}_{4} 4 \mathrm{RO}^{+}$and $\mathrm{CD}^{2} 5 \mathrm{RO}^{-} \mathrm{T}$ cells. We therefore determined the percentage of memory $\mathrm{CD} 4^{+} \mathrm{T}$ cells with a regulatory phenotype $\left(\mathrm{CD} 25^{+} \mathrm{CD} 127^{\mathrm{low}}\right)$ in $\mathrm{PB}$ and SF from patients with RA, and in PB from healthy controls (HC) (gating strategy shown in Supplementary Figure 3). Our data show that there was no significant difference in the percentage of $\mathrm{CD} 25^{+} \mathrm{CD} 127^{\text {low }}$ cells within $\mathrm{CD}^{+} \mathrm{CD} 4{ }^{+} \mathrm{CD} 45 \mathrm{RO}^{+} \mathrm{T}$ cells in the peripheral blood of patients with RA $(n=29)$ and $\mathrm{HC}(\mathrm{n}=36)(10 \pm 0.5 \%$ vs. $11 \pm 0.7 \%$, Figure $1 \mathrm{~A})$, even after correcting for age differences between the groups (data not shown). However, the percentage of $\mathrm{CD} 25^{+} \mathrm{CD} 127^{\text {low }}$ cells within $\mathrm{CD}^{+} \mathrm{CD} 4{ }^{+} \mathrm{CD} 45 \mathrm{RO}^{+} \mathrm{T}$ cells was significantly elevated in $\mathrm{SF}(\mathrm{n}=12)(23 \pm 2.0 \%, \mathrm{p}<0.0001)$ compared to $\mathrm{PB}(\mathrm{n}=29)$ from patients with RA (Figure 1A). A similar increase was observed when analysing paired PB and SF samples only $(\mathrm{n}=11, \mathrm{p}=0.0005)$. We also determined the presence of $\mathrm{CD} 14^{+}$monocytes in $\mathrm{HC}$ and 
patients with RA, and found a significant increase in the percentage of $\mathrm{CD} 14^{+}$monocytes in PB of patients compared to HC $(19 \pm 2.3 \%$ vs. $13 \pm 1.0 \%, \mathrm{p}<0.05)$, and an even higher percentage at the site of inflammation $(26 \pm 3.5 \%)$ (Figure 1B).

We assessed the phenotype of peripheral blood monocytes (PBM) from patients with RA and healthy controls by flow cytometry. PBM from patients with RA had a significantly higher expression of CD14, CD16, CD40, CD54 and HLA-DR compared to HC (Figure 1C), indicating an activated phenotype. $\mathrm{CD} 14^{+}$monocytes were found to be further activated in SF from patients with RA, as shown by a significantly increased expression of CD16, CD40, CD54 and HLA-DR by SF-derived monocytes (SFM) relative to paired PBM $(\mathrm{n}=7$, Figure 1D). In order to investigate the effect of monocytes with an activated phenotype on human Tregs, we established an in vitro-system using 100ng/ml LPS to activate monocytes from HC. These LPS-treated monocytes (LPS-mono) $(n=18)$ showed a significant upregulation of the activation markers CD40, CD54, CD86 and HLA-DR, but a down-regulation of CD16 compared to medium-treated monocytes (mono-med) (Figure 1E), indicating an in vitro-activated phenotype that is similar but not identical to in vivo-activated SF monocytes.

\section{In vitro-activated monocytes induce cytokine expression in CD4+CD45RO+CD25+CD127low Tregs}

We next assessed the effects of activated monocytes on Treg phenotype and function. $\mathrm{CD} 4{ }^{+} \mathrm{CD} 45 \mathrm{RO}^{+} \mathrm{CD} 25^{+} \mathrm{CD} 127^{\text {low }} \mathrm{T}$ cells (memory Tregs) from healthy controls were sorted to high purity (Supplementary Figure 1) and co-cultured with autologous $\mathrm{CD} 14^{+}$monocytes that had been pre-treated with either 100ng/ml LPS or medium for $30 \mathrm{~min}$ followed by extensive washing. Soluble anti-CD3 mAb was added to the co-cultures to activate Tregs. In the presence of LPS-mono, a significant increase in the percentage of memory Tregs expressing IL-17, IFN $\gamma$ or TNF-a was observed relative to mono-med (Figure 2A-D). Notably, the presence of LPS-mono also significantly increased the percentage of IL- $10^{+}$ Tregs (Figure 2A, E). In order to determine the relative magnitude of the percentage of cytokine-expressing Tregs, we performed a similar analysis within effector memory T cells, by setting up parallel co-cultures of $\mathrm{CD} 4^{+} \mathrm{CD} 45 \mathrm{RO}^{+} \mathrm{CD} 25^{\text {low/- }} \mathrm{CD} 127^{+} \mathrm{T}$ cells (Teff) with medium-treated or LPS-activated monocytes. This analysis showed that although proinflammatory cytokine-expressing Tregs were increased in the presence of activated monocytes, the percentage was still relatively low compared to pro-inflammatory cytokineexpressing Teff (e.g. $3.8 \pm 0.4 \%$ vs. $17 \pm 1.6 \% \mathrm{IL}-17^{+}$cells) (Figure $2 \mathrm{~B}-\mathrm{D}$ ). The percentage of pro-inflammatory cytokine-expressing Tregs was also low compared to unsorted memory $\mathrm{CD}^{+} \mathrm{T}$ cells (data not shown). In contrast, the percentage of IL- $10^{+}$cells was highest in Tregs following incubation with activated monocytes (Figure 2E). Of note, although proinflammatory cytokine-expressing regulatory $\mathrm{T}$ cells are not "Tregs" per definition, for the purpose of clarity, we will continue to refer to these cytokine-expressing $\mathrm{CD} 4{ }^{+} \mathrm{CD} 45 \mathrm{RO}^{+} \mathrm{CD} 25^{+} \mathrm{CD} 127^{\text {low }} \mathrm{T}$ cells as Tregs in this paper.

\section{Cytokine-activated monocytes as well as $\mathrm{CD} 14^{+} \mathrm{CD} 16^{-}$and $\mathrm{CD} 14^{+} \mathrm{CD} 16^{+}$subsets can induce pro-inflammatory cytokine expression in memory Tregs}

The composition of RA synovial fluid varies between patients and contains varying levels of pro- and anti-inflammatory cytokines (Figure 3A) (24). To mimic the environment monocytes may be exposed to in the inflamed joint, we incubated monocytes with either medium (mono-med) or a cocktail of cytokines commonly associated with SF (IL-1 $\beta$, IL-6, IL-17, IFN $\gamma$, IL-10, TNF-a and OPN) (cyto-mono) for $30 \mathrm{~min}$, followed by extensive washing. Monocytes were cultured overnight and their phenotype assessed. A consistent increase in the expression of the monocyte activation markers CD40, CD54, CD86 and HLA-DR, but a concomitant decrease in CD16 was found on cytokine-activated monocytes 
compared to mono-med (Figure 3B, $\mathrm{n}=5$ ), indicating that these cytokine-activated monocytes are similar, but not identical to in vivo-activated SF monocytes (Figure 1D). Coculture experiments revealed that cytokine-activated monocytes also increased the percentage of memory Tregs expressing IL-17, IFN $\gamma$ or TNF-a, and to a lesser extent IL-10 (Figure 3C).

It was shown recently that $\mathrm{CD} 14^{+} \mathrm{CD} 16^{+}$monocytes are increased in $\mathrm{PB}$ of patients with $\mathrm{RA}$ and that this subpopulation of monocytes is most potent in the induction of IL-17 production by $\mathrm{CD}^{+} \mathrm{T}$ cells $(25)$. In agreement with that study, we observed a significant increase in $\mathrm{CD} 14^{+} \mathrm{CD} 16^{+}$monocytes in PB of patients with RA $(\mathrm{n}=22)$ compared to HC $(\mathrm{n}=26)$ $\left(10 \pm 1.2 \%\right.$ vs. $7 \pm 0.6 \%$ of $\mathrm{CD} 14^{+}$monocytes, $\mathrm{p}=0.016$, data not shown). Since MACSisolated $\mathrm{CD} 14^{+}$monocytes contain both "pro-inflammatory" CD14+CD16 ${ }^{+}$and "classical" $\mathrm{CD} 14^{+} \mathrm{CD} 16^{-}$populations, we sorted $\mathrm{CD} 14^{+}$monocytes into $\mathrm{CD} 16^{-}$and $\mathrm{CD} 16^{+}$cells (Supplementary Figure 2) and co-cultured them with memory Tregs with or without LPS. Both CD16 ${ }^{+}$-depleted $\left(\mathrm{CD} 16^{-}\right)$and $\mathrm{CD} 14^{+} \mathrm{CD}_{16}{ }^{+}\left(\mathrm{CD} 16^{+}\right)$monocytes showed a similar capacity as total $\mathrm{CD} 14^{+}$monocytes to induce pro-inflammatory IL-17 and IFN $\gamma$ expression in memory Tregs (Figure 3D, E). Together, these findings indicate that TLR4-stimulated as well as cytokine-activated monocytes can induce pro-inflammatory cytokine expression in $\mathrm{CD}^{+} \mathrm{CD} 45 \mathrm{RO}^{+} \mathrm{CD} 25^{+} \mathrm{CD} 127^{\text {low }}$ Tregs, and that this is not a unique feature of a particular $\mathrm{CD} 14^{+}$monocyte population.

\section{The increased expression of IL-17 and IFNy in memory Tregs is driven by monocyte- derived IL-1 $\beta$, IL- 6 and TNF- $\alpha$}

To determine the mechanism via which activated monocytes drive the observed increase in cytokine-expressing Tregs, we first investigated whether soluble factors were involved. Monocytes were pre-activated with LPS, extensively washed and cultured for $40 \mathrm{hrs}$. Supernatants were collected and transferred to monocyte-Treg co-cultures and intracellular cytokine expression was determined at day 3 . The addition of supernatants from activated monocytes led to a significant increase in IL-17 $7^{+}$Tregs, and a trend towards increased IFN $\gamma^{+}$Tregs $(\mathrm{p}=0.09, \mathrm{n}=6$ ), whilst IL-10 and TNF- $\mathrm{a}$ expression were unaffected (Figure 4A). To elucidate which soluble factors secreted by LPS-mono could drive the increased expression of pro-inflammatory IL-17 and IFN $\gamma$ in memory Tregs, supernatants from monomed and LPS-mono were analysed by a 25-plex cytokine array. LPS-mono produced significantly increased amounts of pro-inflammatory (IL-1 $\beta$, IL-6, TNF-a, IL-12p40/p70) and anti-inflammatory (IL-10) cytokines (Figure 4B), which are also present in SF of patients with RA (Figure 3A and data not shown). IL-1 $\beta$, IL-6 and TNF- $\alpha$ are known inflammatory mediators in the pathogenesis of RA and can drive the induction of IL-17producing T cells (26). To test the role of these cytokines, we performed reconstitution and blocking experiments. Addition of hrIL-1 $\beta$, IL-6 and TNF-a to co-cultures of memory Tregs with monocytes led to an increase in the percentage of $\mathrm{IL}-17^{+}$and IFN $\gamma^{+}$Tregs compared to medium control (Figure 4C). Conversely, neutralisation of IL-1 $\beta$, IL-6 and TNF-a during co-culture of memory Tregs with LPS-mono consistently prevented the increase in IL-17 expression and to some extent IFN $\gamma$ (Figure 4D-F), but did not affect IL-10 or TNF-a expression (data not shown). The addition of neutralising Abs also reduced IL-17 and to a lesser extent IFN $\gamma$ secretion (Figure 4E, F).

\section{CD4 ${ }^{+} C D 45 R 0^{+} C D 25^{+} C D 127^{\text {low }}$ Tregs maintain a regulatory phenotype after co-culture with in vitro-activated monocytes}

We determined whether $\mathrm{CD} 4{ }^{+} \mathrm{CD} 45 \mathrm{RO}^{+} \mathrm{CD} 25^{+} \mathrm{CD} 127^{\text {low }}$ Tregs still displayed a regulatory phenotype following incubation with activated monocytes. After co-culture with LPS-mono, Tregs remained positive for CD25 and CD39 (Figure 5A). A slight increase was seen in the percentage of cells positive for CD69 and HLA-DR, indicating an activated status of the 
cells. Despite the increase in IL-17-expressing cells, we did not observe an increase in the Th17 marker CD161 (27) (Figure 5A). IL-17+ Tregs showed sustained FoxP3 expression following co-culture with activated monocytes (Figure 5B, D). In fact, FoxP3 expression in LPS-mono-activated Tregs was significantly higher in both $\mathrm{IL}-17^{+}$and $\mathrm{IL}-17^{-}$cells compared to their respective mono-med-cultured counterparts (Figure 5B, D). In contrast, virtually all IL- $17^{+}$Teff, which were induced under the same conditions, were FoxP3negative (Figure 5D). IL-17 ${ }^{+}$Tregs from co-cultures with both mono-med and LPS-mono contained a low percentage of Ki-67 ${ }^{+}$cells $(10 \pm 3.1 \%$ and $15 \pm 6.1 \%$, respectively) (Figure $5 \mathrm{C}, \mathrm{E})$ whilst IL- $17^{+}$Teff were pre-dominantly $\mathrm{Ki}-67^{+}(91 \pm 2.7 \%$ and $75 \pm 5.7 \%)$ (Figure 5E, data not shown). Together, these data demonstrate that although $\mathrm{CD}^{+} \mathrm{CD} 45 \mathrm{RO}^{+} \mathrm{CD} 25^{+} \mathrm{CD} 127^{\text {low }}$ Tregs show increased pro-inflammatory cytokine expression following co-culture with activated monocytes, their Treg phenotype is maintained.

\section{Activated memory Tregs show an enhanced capacity to suppress cytokine secretion and T cell proliferation}

Finally, we determined whether enhanced pro-inflammatory cytokine expression in $\mathrm{CD} 4^{+} \mathrm{CD} 45 \mathrm{RO}^{+} \mathrm{CD} 25^{+} \mathrm{CD} 127^{\text {low }}$ Tregs impaired their ability to suppress $\mathrm{T}$ cell proliferation as well as monocyte- and T cell-derived cytokine production. We co-cultured memory Tregs with either mono-med or LPS-mono in the presence of anti-CD3 mAb overnight at various cell ratios to allow interaction between cells. The next day, CFSElabelled, autologous Teff were added to the cultures and proliferation was assessed by flow cytometry two days later. Teff proliferated strongly in the presence of mono-med, which was suppressed by the presence of Tregs (Figure 6A, B). Although Teff proliferated less profoundly in the presence of LPS-activated monocytes, their proliferation was still strongly suppressed by the presence of Tregs. In fact, when we calculated the percentage of suppression of proliferation, we found an increased suppressive capacity when Tregs were pre-cultured with LPS-mono at all Teff:Treg ratios (Figure 6B). We also assessed the suppressive effects of Tregs on the secretion of IL-17 and IFN $\gamma$ by Teff, and found that following interaction with LPS-mono, memory Tregs were more efficient in suppressing cytokine secretion, which was particularly evident for IL-17 (Figure 6C, D); LPS-monoactivated Tregs suppressed IL-17 secretion already at a 1:0.2 ratio (Teff:Treg) whilst monomed-cultured Tregs in most cases only suppressed at a 1:1 ratio (Figure 6D). Finally, the addition of memory Tregs to cultures of LPS-activated monocytes significantly suppressed the secretion of TNF- $a$, IL-1 $\beta$ and IL- 6 by monocytes (Figure 6E), but did not affect IL-10 secretion (data not shown). Overall, these data indicate that monocyte-activated memory Tregs, despite an increased expression of pro-inflammatory cytokines, maintain their Treg phenotype and function, and in fact show an enhanced capacity to suppress $\mathrm{T}$ cell proliferation and IL-17 production.

\section{Discussion}

Here we show that human $\mathrm{CD} 4{ }^{+} \mathrm{CD} 45 \mathrm{RO}^{+} \mathrm{CD} 25^{+} \mathrm{CD} 127^{\text {low }}$ Tregs can be induced to express pro-inflammatory (IL-17, IFN $\gamma$, TNF-a) but also anti-inflammatory (IL-10) cytokines upon interaction with activated monocytes. Importantly, despite the observed increase in pro-inflammatory cytokine expression, Tregs maintain their regulatory phenotype and appear enhanced, rather than impaired, in their ability to suppress $\mathrm{T}$ cell proliferation and cytokine production, and IL-17 in particular. Our data suggest that cytokine-expressing Tregs at sites of inflammation may still exert potent immune suppression.

We found that the increase in IL- $17^{+}$and to a lesser extent IFN $\gamma^{+}$Tregs was driven by monocyte-derived IL-6, TNF- $\alpha$ and IL- $1 \beta$. TNF- $\alpha$ was the most abundantly induced 
cytokine in Tregs following interaction with activated monocytes, and TNF- $\mathrm{a}^{+}$Tregs have also been observed in other in vitro studies $(6,7,11)$. However, the mechanism for induction of TNF-a expression in Tregs appeared different as the addition of supernatants from activated monocytes did not increase TNF- $a$ expression. The induction of IL-10 expression in T cells was relatively small overall, but the percentage of IL- $10^{+}$cells was highest in LPS-mono-activated Tregs $(1.9 \pm 0.3 \%)$. It should be noted that the cytokine expression we report represents the cytokine profile following PMA and ionomycin restimulation. Although this is a very commonly used system for the detection of cytokine-expressing cells, the levels reported may not reflect the actual levels of cytokine-secreting cells.

Various other reports indicate that human $\mathrm{CD}^{+} \mathrm{CD} 25^{+} \mathrm{FoxP} 3^{+}$regulatory $\mathrm{T}$ cells comprise a heterogeneous cell population that can display plasticity during development, differentiation and when exposed to a pro-inflammatory environment (reviewed in $(3,4)$ ). It was shown that human Tregs can be induced in vitro to express the pro-inflammatory cytokine IL-17 following stimulation with $a-C D 3 / C D 28 \mathrm{mAb}$-coated beads in the presence of hrIL-1 $\beta$ and IL-2 (7, 10-13). IL-17 ${ }^{+}$Tregs have also been found in vivo at sites of inflammation including periodontitis lesions (8), psoriatic skin (9), human tonsils (7), and the lamina propria of patients with Crohn's disease (28). Furthermore, Tregs from patients with psoriasis showed an enhanced propensity to differentiate into IL-17-producing cells, which was accompanied by decreased FoxP3 and increased Rorc2 expression (9). These findings overall suggest that Tregs from inflammatory sites may convert into IL-17-producing cells.

The key question is whether human pro-inflammatory cytokine-expressing Tregs maintain their suppressive capacity. Two groups reported that the induction of IL-17 expression in naïve Tregs under inflammatory conditions was accompanied by impaired suppression (11, 12). Single-cell cloning experiments further suggested that Tregs can transiently lose their suppressive function when actively secreting IL-17, but FoxP3 expression was not affected (13). In contrast, $\mathrm{IL}-17^{+}$Treg clones $(6,7,13)$ as well as $\mathrm{IL}-17^{+}$Tregs from the inflamed intestinal mucosa of patients with Crohn's disease, were shown to be suppressive (28). In diabetic patients, IFN $\gamma^{+}$Tregs were reported to be increased, but these cells expressed high levels of FoxP3, and possessed suppressive activity (29). Furthermore, IFN $\gamma$ production by Tregs was recently suggested to be essential for the prevention of Graft-versus-Host disease (30). Although care needs to be taken when extrapolating in vitro data into the in vivo situation as exemplified by a preclinical model for xenogeneic Graft-versus-Host-Disease (31), our data suggest that Tregs exposed to an inflammatory environment may have enhanced suppressive effects particularly on T cell proliferation and IL-17 production, despite the fact that Tregs themselves become more IL-17+. Th17 cells are thought to be more resistant to Treg-mediated suppression (32-35), and our findings that an increase in IL-17+ Tregs corresponds with enhanced suppression of Th17 cells are in line with elegant studies in mice demonstrating that Tregs adapt to their cytokine milieu through the upregulation of specific transcription factors, thus ensuring appropriate $\mathrm{T}$ helper-specific control of inflammation (36-38). Together, these data suggest that the induction of proinflammatory cytokine expression in Tregs is not indicative per se of a conversion towards a less suppressive and/or more pathogenic function. Instead, this should be seen in context of the other cytokines Tregs produce (e.g. IL-10), their level of cytokine expression relative to Teff, and their regulatory phenotype and function.

Our findings may have physiological relevance since we show that memory Tregs and activated monocytes are present in abundance in the inflamed rheumatic joint. The welldocumented presence of T cells with a regulatory phenotype and function in SF from patients with RA (16-23) thus leaves the paradox as to why inflammation persists despite the presence of these potentially suppressive cells. It has been shown that addition of proinflammatory mediators such as IL-7 or TNF-a in vitro can break Treg function (39). TNF- 
a was also found to downregulate FoxP3 expression and function in humans Tregs (40). Furthermore, DC-derived IL-6 was shown to abrogate Treg-mediated suppression in mice (41), to increase IL-17 production (42), and to induce a loss in FoxP3 expression, which was exacerbated in the presence of IL-1 $\beta$ (43). Inhibition of IL-6 using tocilizumab, a humanised anti-IL-6R antibody, was shown to correct for the imbalance of Th17 cells to Tregs in RA (44) and enhanced the suppressive capacity of SF-derived Tregs (45). A recent study showed that the ability to control monocyte-derived IL-6 production was critical for the ability of Tregs to suppress Th17 responses in patients with RA (46). It should be noted however, that the aforementioned studies do not always allow a distinction between impaired Treg function vs. increased resistance of Teff to suppression. Our data also show a distinct effect of IL-1 $\beta$, IL- 6 and TNF- $\alpha$ on Tregs, since we found that increased IL-17 and IFN $\gamma$ expression in Tregs was driven by these cytokines. Notwithstanding the above mentioned effects of TNF-a, IL- 6 and IL- $1 \beta$ on Treg phenotype and function in vitro, it is evident that SF-derived Tregs are fully suppressive ex vivo $(17-23,47)$ and in fact, may even be more suppressive than their PB counterparts $(17,47)$. Recent data also revealed a fully demethylated FoxP3 promoter region in SF-derived Tregs, indicating that these cells may indeed be "true" Tregs, despite low level IL-17 and IFN $\gamma$ expression upon stimulation (45). Thus, Tregs at sites of inflammation may not be intrinsically defective. Instead, possible defects in immunoregulation may reside within the activated Teff population that becomes resistant to Treg-mediated suppression (17, 48-50).

In conclusion, our data - together with the existing literature - provide evidence that Tregs that have been exposed to an inflammatory environment express pro-inflammatory cytokines but may maintain their suppressive capacity, and in fact may be strengthened rather than weakened in their function.

\section{Supplementary Material}

Refer to Web version on PubMed Central for supplementary material.

\section{Acknowledgments}

The authors are grateful to all donors and patients who consented to participate in this study. This work was supported by Arthritis Research UK, the IMI JU funded project BeTheCure, contract no 115142-2, by the National Institute for Health Research (NIHR) Biomedical Research Centre based at Guy's and St Thomas' NHS Foundation Trust and King's College London. The views expressed are those of the author(s) and not necessarily those of the NHS, the NIHR or the Department of Health. We would like to thank Susanne Heck, Helen Graves and Pj Chana for their help in cell sorting at the BRC Flow Core Facility. The authors would like to acknowledge Ms Cristina Blanco-Gil for help in patient recruitment and data collection.

This work was financially supported by Arthritis Research UK, the IMI JU funded project BTCure 115142-2, and the Department of Health via the National Institute for Health Research (NIHR) Biomedical Research Centre (BRC) award to Guy's \& St Thomas' NHS Foundation Trust in partnership with King's College London and King's College Hospital NHS Foundation Trust.

\section{References}

1. Sakaguchi S, Miyara M, Costantino CM, Hafler DA. FOXP3+ regulatory T cells in the human immune system. Nat Rev Immunol. 2010; 10(7):490-500. [PubMed: 20559327]

2. Shevach EM. Mechanisms of Foxp3+ T regulatory cell-mediated suppression. Immunity. 2009; 30(5):636-45. [PubMed: 19464986]

3. Hori S. Developmental plasticity of Foxp3+ regulatory T cells. Curr Opin Immunol. 2010; 22(5): 575-82. [PubMed: 20829012]

4. Zhou X, Bailey-Bucktrout S, Jeker LT, Bluestone JA. Plasticity of CD4(+) FoxP3(+) T cells. Curr Opin Immunol. 2009; 21(3):281-5. [PubMed: 19500966] 
5. Miyara M, Yoshioka Y, Kitoh A, Shima T, Wing K, Niwa A, et al. Functional delineation and differentiation dynamics of human CD4+ T cells expressing the FoxP3 transcription factor. Immunity. 2009; 30(6):899-911. [PubMed: 19464196]

6. Ayyoub M, Deknuydt F, Raimbaud I, Dousset C, Leveque L, Bioley G, et al. Human memory FOXP3+ Tregs secrete IL-17 ex vivo and constitutively express the $\mathrm{T}(\mathrm{H}) 17$ lineage-specific transcription factor RORgamma t. Proc Natl Acad Sci U S A. 2009; 106(21):8635-40. [PubMed: 19439651]

7. Voo KS, Wang YH, Santori FR, Boggiano C, Arima K, Bover L, et al. Identification of IL-17producing FOXP3+ regulatory T cells in humans. Proc Natl Acad Sci U S A. 2009; 106(12):47938. [PubMed: 19273860]

8. Okui T, Aoki Y, Ito H, Honda T, Yamazaki K. The presence of IL-17+/FOXP3+ double-positive cells in periodontitis. J Dent Res. 2012; 91(6):574-9. [PubMed: 22522772]

9. Bovenschen HJ, van de Kerkhof PC, van Erp PE, Woestenenk R, Joosten I, Koenen HJ. Foxp3+ Regulatory T Cells of Psoriasis Patients Easily Differentiate into IL-17A-Producing Cells and Are Found in Lesional Skin. J Invest Dermatol. 2011; 131(9):1853-60. [PubMed: 21654831]

10. Koenen HJ, Smeets RL, Vink PM, van Rijssen E, Boots AM, Joosten I. Human CD25highFoxp3pos regulatory T cells differentiate into IL-17-producing cells. Blood. 2008; 112(6):2340-52. [PubMed: 18617638]

11. Deknuydt F, Bioley G, Valmori D, Ayyoub M. IL-1beta and IL-2 convert human Treg into T(H)17 cells. Clin Immunol. 2009; 131(2):298-307. [PubMed: 19211307]

12. Valmori D, Raffin C, Raimbaud I, Ayyoub M. Human RORgammat+ TH17 cells preferentially differentiate from naive FOXP3+Treg in the presence of lineage-specific polarizing factors. Proc Natl Acad Sci U S A. 2010; 107(45):19402-7. [PubMed: 20962281]

13. Beriou G, Costantino CM, Ashley CW, Yang L, Kuchroo VK, Baecher-Allan C, et al. IL-17producing human peripheral regulatory T cells retain suppressive function. Blood. 2009; 113(18): 4240-9. [PubMed: 19171879]

14. Wilke CM, Bishop K, Fox D, Zou W. Deciphering the role of Th17 cells in human disease. Trends Immunol. 2011; 32(12):603-11. [PubMed: 21958759]

15. Evans HG, Gullick NJ, Kelly S, Pitzalis C, Lord GM, Kirkham BW, et al. In vivo activated monocytes from the site of inflammation in humans specifically promote Th17 responses. Proc Natl Acad Sci U S A. 2009; 106(15):6232-7. [PubMed: 19325128]

16. Michels-van Amelsfort JM, Walter GJ, Taams LS. CD4(+)CD25(+) regulatory T cells in systemic sclerosis and other rheumatic diseases. Expert Rev Clin Immunol. 2011; 7(4):499-514. [PubMed: 21790293]

17. van Amelsfort JM, Jacobs KM, Bijlsma JW, Lafeber FP, Taams LS. CD4(+)CD25(+) regulatory T cells in rheumatoid arthritis: differences in the presence, phenotype, and function between peripheral blood and synovial fluid. Arthritis Rheum. 2004; 50(9):2775-85. [PubMed: 15457445]

18. Cao D, Malmstrom V, Baecher-Allan C, Hafler D, Klareskog L, Trollmo C. Isolation and functional characterization of regulatory CD25brightCD4+ T cells from the target organ of patients with rheumatoid arthritis. Eur J Immunol. 2003; 33(1):215-23. [PubMed: 12594850]

19. Cao D, van Vollenhoven R, Klareskog L, Trollmo C, Malmstrom V. CD25brightCD4+ regulatory $\mathrm{T}$ cells are enriched in inflamed joints of patients with chronic rheumatic disease. Arthritis Res Ther. 2004; 6(4):R335-46. [PubMed: 15225369]

20. Liu MF, Wang CR, Fung LL, Lin LH, Tsai CN. The presence of cytokine-suppressive CD4+CD25+ T cells in the peripheral blood and synovial fluid of patients with rheumatoid arthritis. Scand J Immunol. 2005; 62(3):312-7. [PubMed: 16179019]

21. Mottonen M, Heikkinen J, Mustonen L, Isomaki P, Luukkainen R, Lassila O. CD4+ CD25+ T cells with the phenotypic and functional characteristics of regulatory $\mathrm{T}$ cells are enriched in the synovial fluid of patients with rheumatoid arthritis. Clin Exp Immunol. 2005; 140(2):360-7. [PubMed: 15807863]

22. Benito-Miguel M, Garcia-Carmona Y, Balsa A, Perez de Ayala C, Cobo-Ibanez T, Martin-Mola E, et al. A dual action of rheumatoid arthritis synovial fibroblast IL-15 expression on the equilibrium between CD4+CD25+ regulatory T cells and CD4+CD25-responder T cells. J Immunol. 2009; 183(12):8268-79. [PubMed: 20007590] 
23. Raghavan S, Cao D, Widhe M, Roth K, Herrath J, Engstrom M, et al. FOXP3 expression in blood, synovial fluid and synovial tissue during inflammatory arthritis and intra-articular corticosteroid treatment. Ann Rheum Dis. 2009; 68(12):1908-15. [PubMed: 19066178]

24. McInnes IB, Schett G. Cytokines in the pathogenesis of rheumatoid arthritis. Nat Rev Immunol. 2007; 7(6):429-42. [PubMed: 17525752]

25. Rossol M, Kraus S, Pierer M, Baerwald C, Wagner U. The CD14(bright) CD16+ monocyte subset is expanded in rheumatoid arthritis and promotes Th17 expansion. Arthritis Rheum. 2011; 64(3): 671-7. [PubMed: 22006178]

26. Korn T, Bettelli E, Oukka M, Kuchroo VK. IL-17 and Th17 Cells. Annu Rev Immunol. 2009; 27:485-517. [PubMed: 19132915]

27. Cosmi L, De Palma R, Santarlasci V, Maggi L, Capone M, Frosali F, et al. Human interleukin 17producing cells originate from a CD161+CD4+ T cell precursor. J Exp Med. 2008; 205(8):190316. [PubMed: 18663128]

28. Hovhannisyan Z, Treatman J, Littman DR, Mayer L. Characterization of interleukin-17-producing regulatory $\mathrm{T}$ cells in inflamed intestinal mucosa from patients with inflammatory bowel diseases. Gastroenterology. 2011; 140(3):957-65. [PubMed: 21147109]

29. McClymont SA, Putnam AL, Lee MR, Esensten JH, Liu W, Hulme MA, et al. Plasticity of human regulatory $\mathrm{T}$ cells in healthy subjects and patients with type 1 diabetes. J Immunol. 2011; 186(7): 3918-26. [PubMed: 21368230]

30. Koenecke C, Lee CW, Thamm K, Fohse L, Schafferus M, Mittrucker HW, et al. IFN-gamma Production by Allogeneic Foxp3+ Regulatory T Cells Is Essential for Preventing Experimental Graft-versus-Host Disease. J Immunol. 2012; 189(6):2890-6. [PubMed: 22869903]

31. Vercoulen Y, Guichelaar T, Meerding J, Emmelot M, Pingen M, Storm G, et al. Application of cultured human regulatory $\mathrm{T}$ cells requires preclinical in vivo evaluation. J Allergy Clin Immunol. 2012; 129(3):852-5 e3. [PubMed: 22168999]

32. Evans HG, Suddason T, Jackson I, Taams LS, Lord GM. Optimal induction of T helper 17 cells in humans requires $\mathrm{T}$ cell receptor ligation in the context of Toll-like receptor-activated monocytes. Proc Natl Acad Sci U S A. 2007; 104(43):17034-9. [PubMed: 17942669]

33. Lohr J, Knoechel B, Wang JJ, Villarino AV, Abbas AK. Role of IL-17 and regulatory T lymphocytes in a systemic autoimmune disease. J Exp Med. 2006; 203(13):2785-91. [PubMed: 17130300]

34. Annunziato F, Cosmi L, Santarlasci V, Maggi L, Liotta F, Mazzinghi B, et al. Phenotypic and functional features of human Th17 cells. J Exp Med. 2007; 204(8):1849-61. [PubMed: 17635957]

35. O'Connor RA, Taams LS, Anderton SM. Translational mini-review series on Th17 cells: CD4 T helper cells: functional plasticity and differential sensitivity to regulatory $\mathrm{T}$ cell-mediated regulation. Clin Exp Immunol. 2010; 159(2):137-47. [PubMed: 19912249]

36. Chaudhry A, Rudra D, Treuting P, Samstein RM, Liang Y, Kas A, et al. CD4+ regulatory T cells control TH17 responses in a Stat3-dependent manner. Science. 2009; 326(5955):986-91. [PubMed: 19797626]

37. Koch MA, Tucker-Heard G, Perdue NR, Killebrew JR, Urdahl KB, Campbell DJ. The transcription factor T-bet controls regulatory $\mathrm{T}$ cell homeostasis and function during type 1 inflammation. Nat Immunol. 2009; 10(6):595-602. [PubMed: 19412181]

38. Zheng Y, Chaudhry A, Kas A, deRoos P, Kim JM, Chu TT, et al. Regulatory T-cell suppressor program co-opts transcription factor IRF4 to control T(H)2 responses. Nature. 2009; 458(7236): 351-6. [PubMed: 19182775]

39. van Amelsfort JM, van Roon JA, Noordegraaf M, Jacobs KM, Bijlsma JW, Lafeber FP, et al. Proinflammatory mediator-induced reversal of CD4+,CD25+ regulatory T cell-mediated suppression in rheumatoid arthritis. Arthritis Rheum. 2007; 56(3):732-42. [PubMed: 17328044]

40. Valencia X, Stephens G, Goldbach-Mansky R, Wilson M, Shevach EM, Lipsky PE. TNF downmodulates the function of human CD4+CD25hi T-regulatory cells. Blood. 2006; 108(1):25361. [PubMed: 16537805]

41. Pasare C, Medzhitov R. Toll pathway-dependent blockade of CD4+CD25+ T cell-mediated suppression by dendritic cells. Science. 2003; 299(5609):1033-6. [PubMed: 12532024] 
42. Xu L, Kitani A, Fuss I, Strober W. Cutting edge: regulatory T cells induce CD4+CD25-Foxp3-T cells or are self-induced to become Th17 cells in the absence of exogenous TGF-beta. J Immunol. 2007; 178(11):6725-9. [PubMed: 17513718]

43. Yang XO, Nurieva R, Martinez GJ, Kang HS, Chung Y, Pappu BP, et al. Molecular antagonism and plasticity of regulatory and inflammatory T cell programs. Immunity. 2008; 29(1):44-56. [PubMed: 18585065]

44. Samson M, Audia S, Janikashvili N, Ciudad M, Trad M, Fraszczak J, et al. Inhibition of IL-6 function corrects Th17/Treg imbalance in rheumatoid arthritis patients. Arthritis Rheum. 2012; 64(8):2499-503. [PubMed: 22488116]

45. Herrath J, Muller M, Amoudruz P, Janson P, Michaelsson J, Larsson PT, et al. The inflammatory milieu in the rheumatic joint reduces regulatory T-cell function. Eur J Immunol. 2011; 41(8): 2279-90. [PubMed: 21607944]

46. McGovern JL, Nguyen DX, Notley CA, Mauri C, Isenberg DA, Ehrenstein MR. Th17 cells are restrained by regulatory $\mathrm{T}$ cells from patients responding to anti-TNF antibody therapy via inhibition of IL-6. Arthritis Rheum. 2012; 64(10):3129-38. [PubMed: 22674488]

47. de Kleer IM, Wedderburn LR, Taams LS, Patel A, Varsani H, Klein M, et al. CD4+CD25bright regulatory $\mathrm{T}$ cells actively regulate inflammation in the joints of patients with the remitting form of juvenile idiopathic arthritis. J Immunol. 2004; 172(10):6435-43. [PubMed: 15128835]

48. Haufe S, Haug M, Schepp C, Kuemmerle-Deschner J, Hansmann S, Rieber N, et al. Impaired suppression of synovial fluid CD4+CD25-T cells from patients with juvenile idiopathic arthritis by CD4+CD25+ Treg cells. Arhritis Rheum. 2011; 63(10):3153-62. [PubMed: 21702013]

49. Schneider A, Rieck M, Sanda S, Pihoker C, Greenbaum C, Buckner JH. The effector T cells of diabetic subjects are resistant to regulation via CD4+ FOXP3+ regulatory T cells. J Immunol. 2008; 181(10):7350-5. [PubMed: 18981158]

50. Wehrens EJ, Mijnheer G, Duurland CL, Klein M, Meerding J, van Loosdregt J, et al. Functional human regulatory $\mathrm{T}$ cells fail to control autoimmune inflammation due to $\mathrm{PKB} / \mathrm{c}$-akt hyperactivation in effector cells. Blood. 2011; 118(13):3538-48. [PubMed: 21828127] 


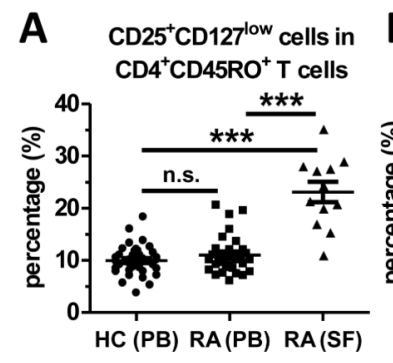

D

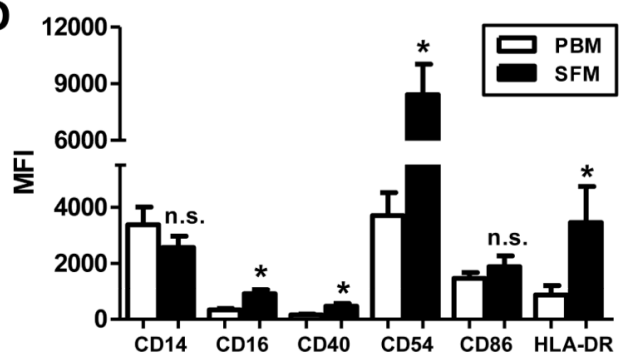

B CD14 cells in PBMC/SFMC C
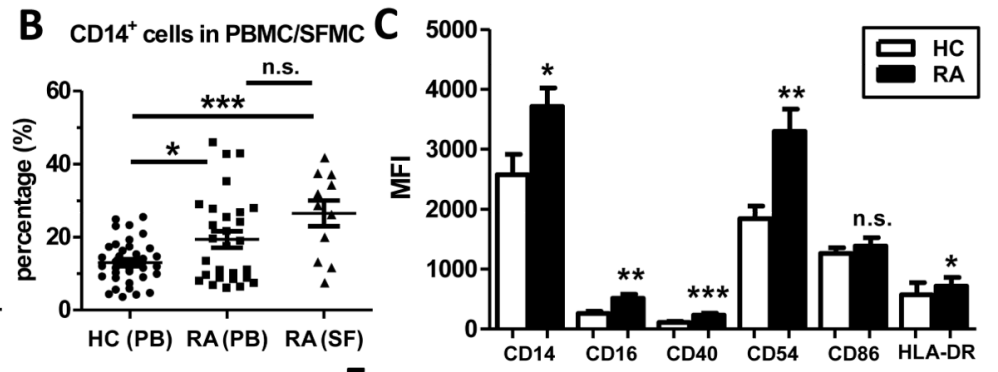

E

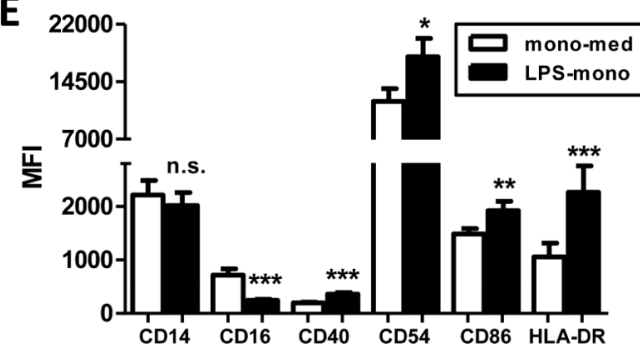

Figure 1. Memory $\mathrm{CD4}^{+} \mathrm{T}$ cells with a Treg phenotype and activated $\mathrm{CD}^{+} 4^{+}$monocytes are increased at the site of inflammation in patients with $R A$

(A, B) Mononuclear cells from PB of healthy controls (HC, $n=36)$ and from PB $(n=28-29)$ and $\mathrm{SF}(\mathrm{n}=11-12)$ from patients with RA were analysed for the percentage of $\mathrm{CD} 25^{+} \mathrm{CD} 127^{\text {low }}$ cells within $\mathrm{CD} 4{ }^{+} \mathrm{CD} 45 \mathrm{RO}^{+} \mathrm{T}$ cells $(\mathrm{A})$ and for the percentage of CD14 ${ }^{+}$ cells in PBMC/SFMC. Lines indicate mean \pm SEM; data were analysed by ANOVA: * $\mathrm{p}<0.05$, *** $\mathrm{p}<0.001$. (C-E) Surface expression of the indicated markers was determined in PB CD14 ${ }^{+}$monocytes (PBM) from patients with RA $(n=17)$ and $\mathrm{HC}(\mathrm{n}=16)(\mathrm{C})$, in paired PBM and SF-derived CD14 ${ }^{+}$monocytes (SFM) from patients with RA (n=7) (D) and in PBM from HC $(\mathrm{n}=18)$ that were treated with medium (mono-med) or LPS (LPS-mono) for 30 min and cultured for 16 hours (E). Results are shown as mean \pm SEM and analysis was performed using Wilcoxon matched-pairs signed rank test: * $\mathrm{p}<0.05$, $* * \mathrm{p}<0.01$, *** $\mathrm{p}<0.001$. 

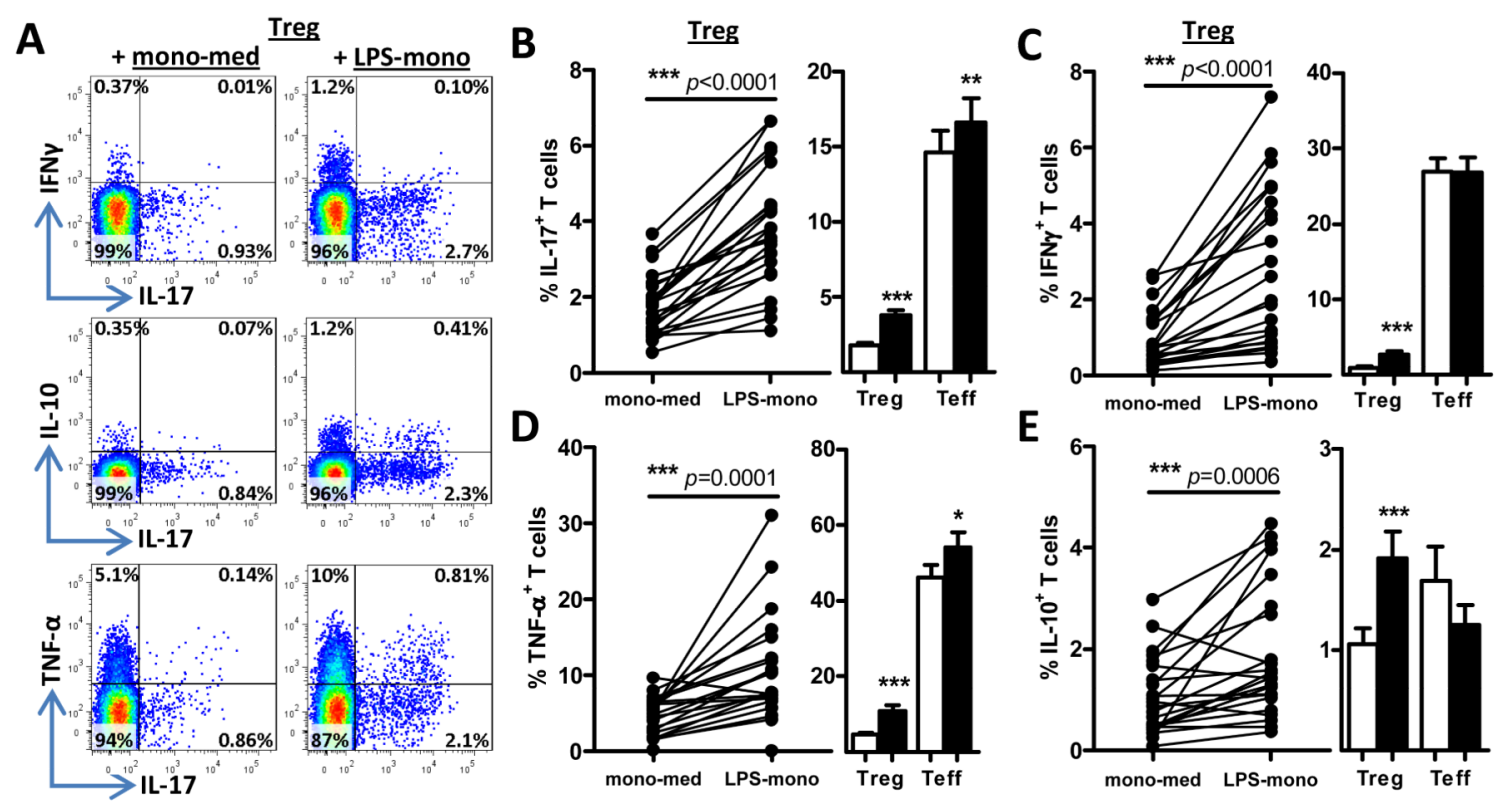

Figure 2. In vitro-activated monocytes induce cytokine expression in $\mathrm{CD}^{+} \mathrm{CD}^{+} \mathrm{RO}^{+} \mathrm{CD}^{+}{ }^{+} \mathrm{CD}_{27}{ }^{\text {low }}$ Tregs

(A-E) Sorted CD $4^{+} \mathrm{CD} 45 \mathrm{RO}^{+} \mathrm{CD} 25^{+} \mathrm{CD} 127^{\text {low }}$ (Tregs) or

$\mathrm{CD} 4^{+} \mathrm{CD} 45 \mathrm{RO}^{+} \mathrm{CD} 25^{-/{ }^{\prime}} \mathrm{CD}_{127^{+}} \mathrm{T}$ cells (Teff) were co-cultured with autologous $\mathrm{CD} 14^{+}$ monocytes, which were either pre-treated with medium or LPS, in the presence of anti-CD3 $\mathrm{mAb}$. After 3 days, cells were re-stimulated with PMA and ionomycin for 6 hours, with GolgiStop present for the last 3 hours and intracellularly stained for IL-17 (B), IFN $\gamma$ (C), TNF-a (D) and IL-10 (E). Dot plots of one representative experiment from co-cultures of Tregs with monocytes (A), and the individual (Treg) and cumulative data from 18-23 experiments (B-E) of either Treg or Teff co-cultures with monocytes are shown. Results are plotted as $\%$ of $\mathrm{CD} 2{ }^{+} \mathrm{CD} 14^{-}$cells expressing the indicated cytokine (mean $\pm \mathrm{SEM}$ ); data were analysed using Wilcoxon matched-pairs signed rank test: $* \mathrm{p}<0.05$, ** $\mathrm{p}<0.01$, *** $\mathrm{p}<0.001$. 

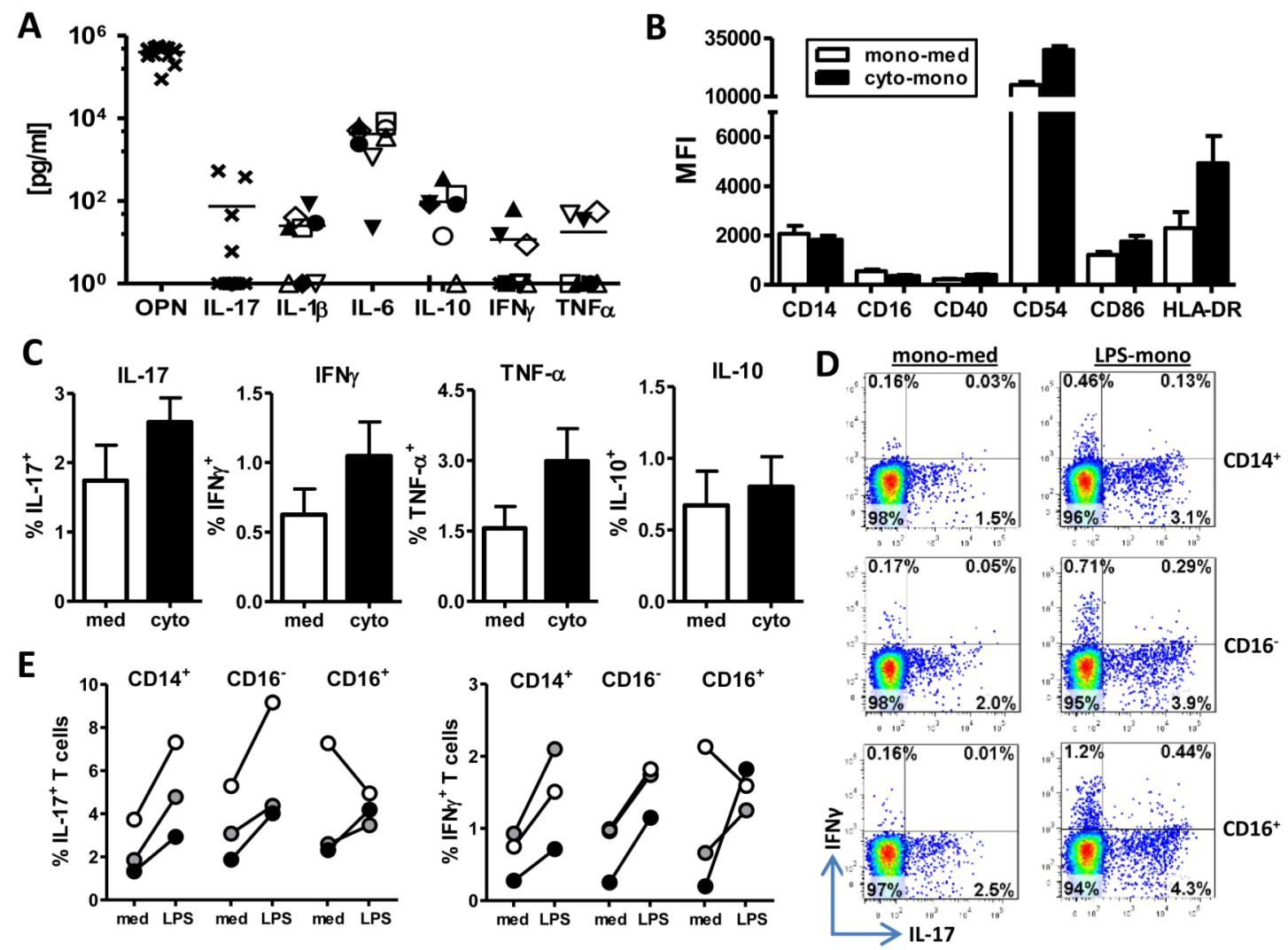

Figure 3. Cytokine-activated monocytes as well as $\mathrm{CD}^{+}{ }^{+} \mathrm{CD}^{-}{ }^{-}$and $\mathrm{CD}^{+} 4^{+} \mathrm{CD}^{+}{ }^{+}$subsets can induce pro-inflammatory cytokine expression in memory Tregs

(A) The presence of cytokines in RA SF (n=8-13) was determined by ELISA or a

FlowCytomix Th1/Th2 assay for the indicated cytokines. For TNF-a, IL-1 $\beta$, IL-6, IFN $\gamma$ and

IL-10 identical symbols reflect the same sample. (B) Expression of the indicated markers was determined on cytokine-activated monocytes (cyto-mono) and compared to mediumtreated monocytes (mono-med) from $\mathrm{HC}(\mathrm{n}=5)$. (C) Memory Tregs were co-cultured with medium-treated (med) or cytokine-activated monocytes (cyto) from $\mathrm{HC}$ in the presence of anti-CD3 mAb for 3 days and the percentage of cytokine-expressing T cells was assessed by ICCS (n=5). (D, E) Memory Tregs were co-cultured with MACS-isolated total CD14 ${ }^{+}$ monocytes, or with sorted $\mathrm{CD} 14^{+} \mathrm{CD} 16^{-}$or $\mathrm{CD} 14^{+} \mathrm{CD} 16^{+}$monocytes in the presence (LPS) or absence (med) of LPS, with anti-CD3 mAb added. The percentage of IL- $17^{+}$or IFN $\gamma^{+} \mathrm{T}$ cells was analysed at day 3 by ICCS after re-stimulation with PMA and ionomycin. Dot plots of one representative experiment (D) and the individual data of 3 experiments (E) are shown. 

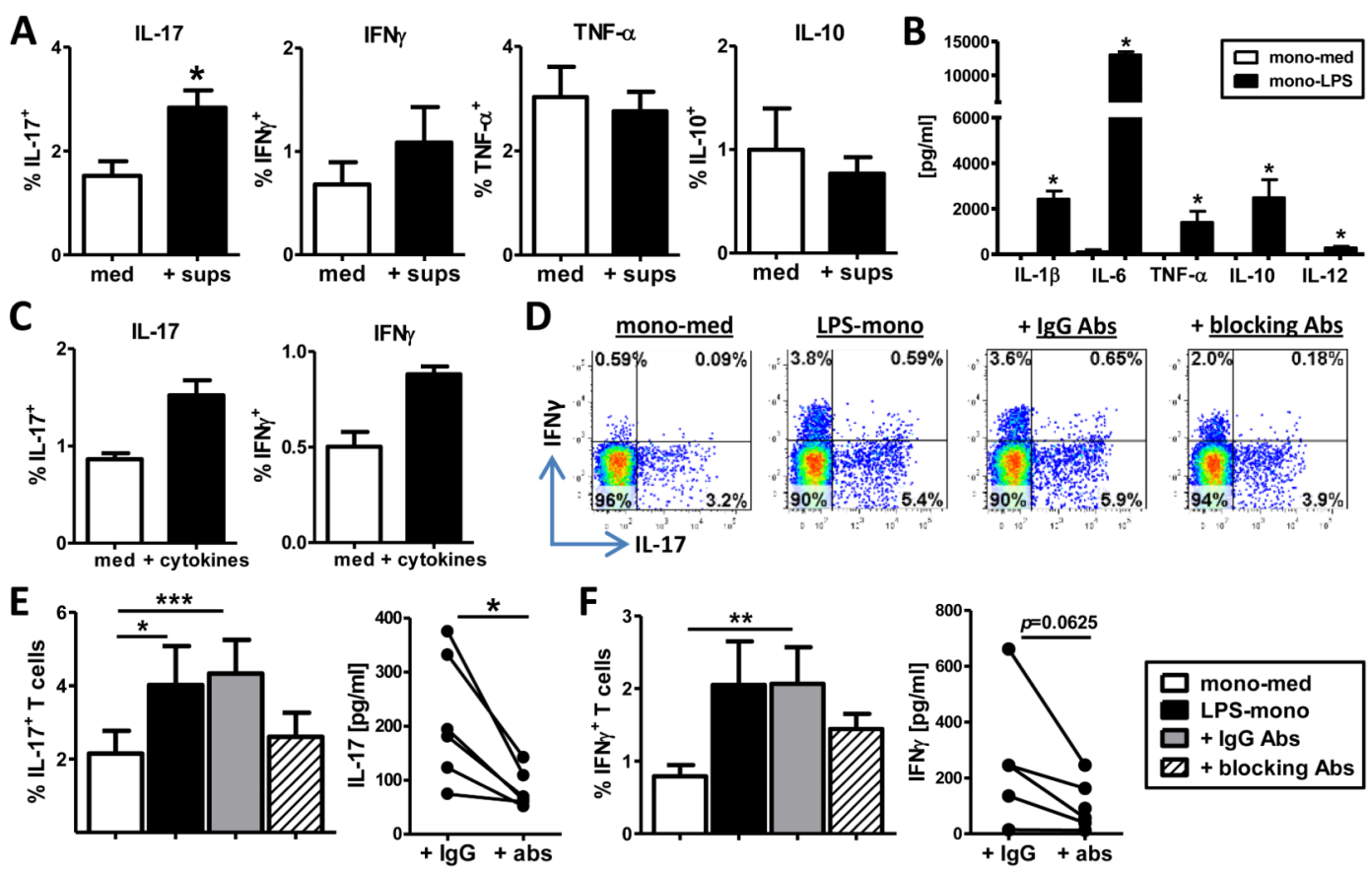

Figure 4. Increased IL-17 and IFN $\gamma$ expression in memory Tregs is mediated by monocytederived IL-1 $\beta$, IL-6 and TNF- $\alpha$

(A) $\mathrm{CD} 4{ }^{+} \mathrm{CD} 45 \mathrm{RO}^{+} \mathrm{CD} 25^{+} \mathrm{CD} 127^{\text {low }}$ Tregs were co-cultured with mono-med alone or with the addition of supernatants from LPS-pre-treated monocytes (sups) in the presence of antiCD3 mAb. The percentage of cytokine-expressing $\mathrm{T}$ cells was determined as described in Figure 2 (mean \pm SEM, $n=6$ ). (B) Monocytes from HC were pre-treated with medium or LPS $(100 \mathrm{ng} / \mathrm{ml})$ and cultured for 40 hours. Supernatants were quantified by 25 -plex cytokine array (mean \pm SEM, $n=6$ ). (C) Sorted memory Tregs were co-cultured with monomed for 3 days with or without hrIL-1 $\beta$, IL-6 and TNF-a, and IL-17 and IFN $\gamma$ expression assessed ( $n=3)$. (D-F) Memory Tregs were co-cultured with mono-med, LPS-mono or LPSmono and neutralising antibodies against IL-1 $\beta$, IL-6 and TNF- $a$ (blocking Abs) or the appropriate IgG isotype controls (IgG Abs). At day 3, cells were analysed for IL-17 (E) and IFN $\gamma(\mathrm{F})$ expression by ICCS and secretion by ELISA. One representative experiment (D) and the cumulative data (mean \pm SEM, $n=6)(E, F)$ are shown. Data were analysed by Wilcoxon matched-pairs signed rank test or Friedman test with Dunn's Multiple Comparison Test: * $\mathrm{p}<0.05, * * \mathrm{p}<0.01, * * * \mathrm{p}<0.001$. 
A

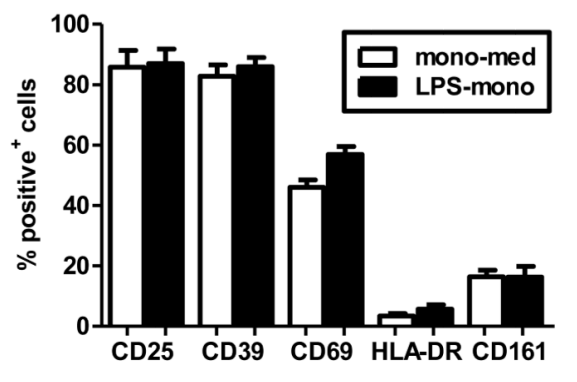

B

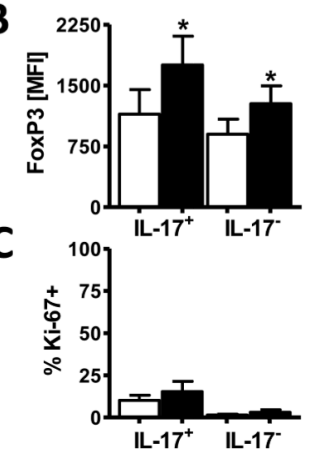

D
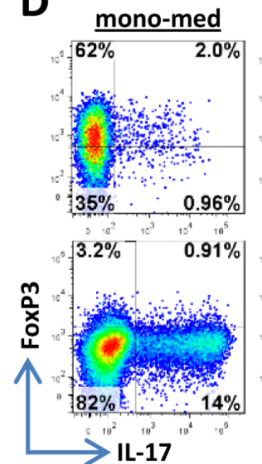

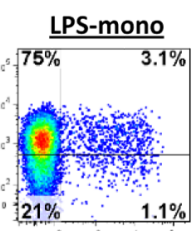

E
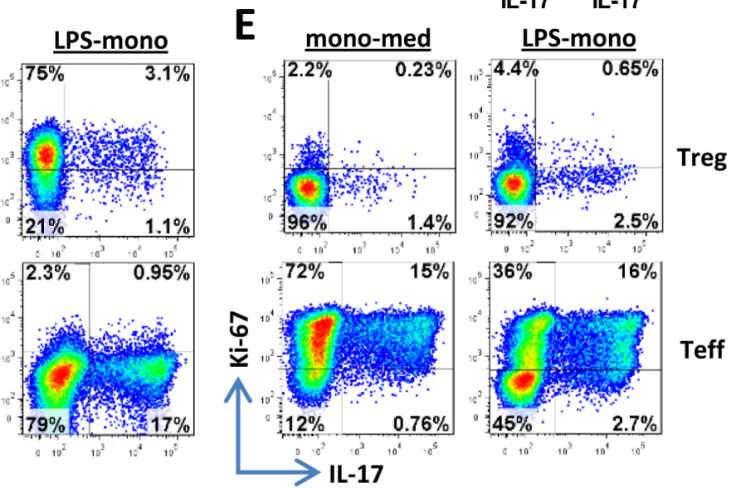

Figure 5. $\mathrm{CD}^{+} \mathrm{CD}^{2} 5 \mathrm{RO}^{+} \mathrm{CD}^{+} 5^{+} \mathrm{CD} 127^{\text {low }} \mathrm{T}$ cells maintain a Treg phenotype after co-culture with activated monocytes

(A) $\mathrm{CD} 4{ }^{+} \mathrm{CD} 45 \mathrm{RO}^{+} \mathrm{CD} 25^{+} \mathrm{CD} 127^{\text {low }}$ Tregs were co-cultured with mono-med or LPS-mono in the presence of anti-CD3 mAb. At day 3, cells were stained for CD69, CD25, CD39, HLA-DR and CD161. Data $\left(n=3\right.$, mean \pm SEM) are shown as the $\%$ of $C D 2{ }^{+} C D 14^{-}$cells expressing the indicated marker. (B-E) Memory Tregs or Teff of a three day culture with monocytes were intranuclearly stained for FoxP3, Ki-67 and IL-17 after a PMA/ionomycin re-stimulation. Data depict the average data (mean \pm SEM, $n=6$ ) of FoxP3 expression (B) and the percentage of Ki-67-positive cells within $\mathrm{IL}-17^{+}$and $\mathrm{IL}-17^{-} \mathrm{CD} 2^{+} \mathrm{CD} 14^{-}$cells $(\mathrm{C})$ with representative dot plots showing FoxP3 vs. IL-17 (D) and Ki-67 vs. IL-17 (E) for Tregs and Teff. Data were analysed using Wilcoxon matched-pairs signed rank test: * $\mathrm{p}<0.05$. 

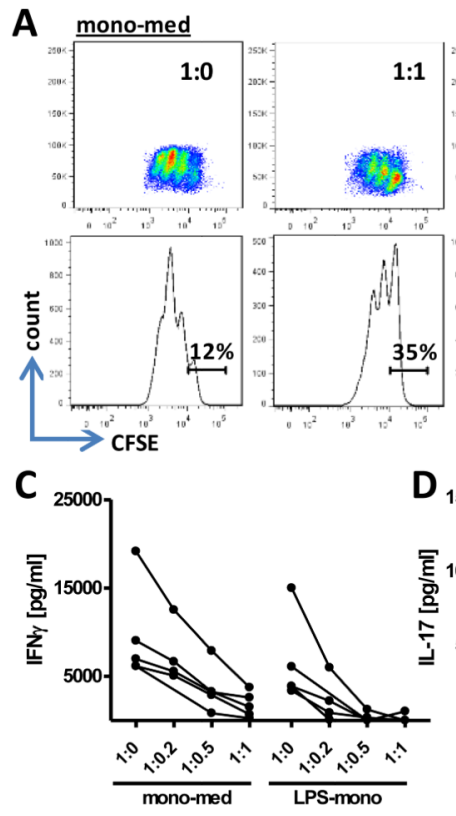

LPS-mono
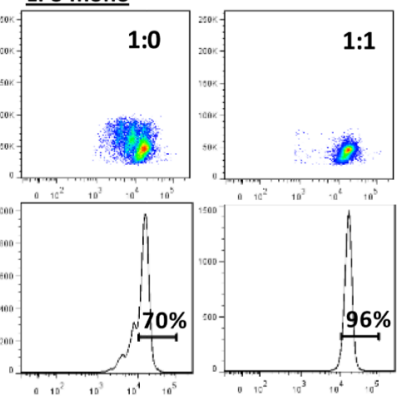

B

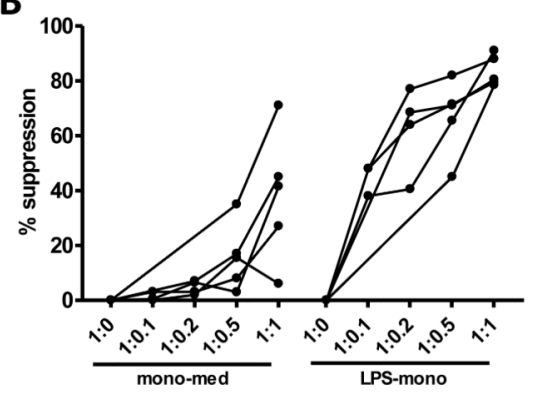

Figure 6. Activated memory Tregs show an enhanced capacity to suppress $\mathbf{T}$ cell proliferation and IL-17 production

(A-D) Sorted CD4 ${ }^{+} \mathrm{CD} 45 \mathrm{RO}^{+} \mathrm{CD} 25^{+} \mathrm{CD} 127^{\text {low }}$ Tregs $\left(1-5 \times 10^{4}\right)$ were co-cultured overnight with $5 \times 10^{4}$ mono-med or LPS-mono in the presence of anti-CD3 mAb at the indicated cell ratios. The next day, CFSE-labelled memory Teff $\left(5 \times 10^{4}\right)$ were added to the co-cultures and proliferation was assessed on day 3 . Dot plots and histograms from one representative experiment $(\mathrm{A})$ and the percentage suppression of proliferation for the individual experiments $(n=5)(B)$ are shown. Supernatants from the co-cultures in $(A, B)$ were analysed for IFN $\gamma(C)$ and IL-17 secretion (D) by ELISA. (E) Supernatants from cell cultures of monocytes with or without Tregs (no T) were collected at day 3 and analysed for TNF-a $(n=14)$, IL-1 $\beta(n=15)$ and IL-6 $(n=13)$ secretion. Analysis was performed using Wilcoxon matched-pairs signed rank test: $* * * \mathrm{p}<0.001$. 